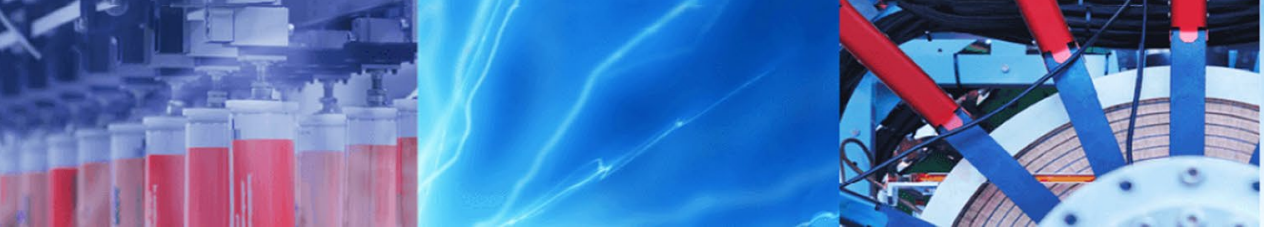

Research Article

\title{
Geospatial analysis of landfill site selection perspectives using geographic information systems in Bongo district, Ghana
}

\author{
Ramatu Agana Amoah ${ }^{1}$ (D) . Matthew Biniyam Kursah ${ }^{1}$ (D)
}

(c) Springer Nature Switzerland AG 2019

\begin{abstract}
This study applied geospatial tools in geographic information systems (GIS) to produce five different landfill suitability maps using criteria selection and prioritisation from the governmental guideline, the local technocrats, the indigenes and two optimal options, which are made up of the harmonisation of the three perspectives. The results from the five perspectives are compared and analysed using the error index technique. The results showed a low spatial agreement (low degree of matching) between the landfill suitability from the governmental guideline and the rest of the perspectives. It also showed a consistent reduction in the areas classified as suitable landfill sites from the governmental guideline to the indigenous perspective. The governmental guideline, thus, exhibits wider spatial discrepancy from the perspective of the local technocrats, and it is even incongruent with that of the indigenes. This study, therefore, exposed a classical case where proponents of landfill sites could meet the governmental guideline and legally acquire permit, but the site could be socioculturally disruptive to the residents. This is identified as the potential source of residents' opposition to landfill siting. The challenges of the criteria in the guideline are also highlighted. A revision of the guideline is suggested, as it is risk-seeking in its current form. Based on this, the bottom-up approach for designing landfill guidelines is recommended.
\end{abstract}

Keywords Bongo · Error index · Landfill siting · Landfill suitability $\cdot$ Local participation · Local opposition

\section{Introduction}

Waste management is an important environmental issue associated with urbanisation. With the current trends of rapid urbanisation and population growth, waste disposal has become a major problem. Despite being a by-product of urban lifestyle, waste is growing at a faster rate than urbanisation in most countries [1]. The integrated waste management systems are adopted to deal with this problem. This consists of a hierarchy of four components involving, in that order, (1) source reduction, (2) recycling, (3) combustion with energy recovery and (4) disposal through landfilling. Even with the increased emphasis on the first three strategies, landfilling is still the most common method in waste management [2-4], especially in developing countries such as Ghana. The landfill seems to have a special attraction for waste managers because it offers a cheap and convenient option for waste disposal compared with the other three strategies. Also, no matter what strategy of waste reduction and recycling/recovery is implemented, some amount of waste and waste residues will always be disposed of in landfills [5].

In Ghana, waste managers face problems with both the collection and management of waste from the urban environment due in part to lack of proper landfill sites. Thus, the urban environments are characterised by heaps of garbage, overflowing waste containers, choked drains, clogged streams and stinking gutters [5-7], which has been described as a nightmare [6]. As the amount of waste is projected to increase by 2025 in the country [1], the problem could only get worst if pragmatic interventions are not put in place to manage the waste. The Bongo

Matthew Biniyam Kursah, mkursah@uew.edu.gh | 'Department of Geography Education, University of Education, Winneba (UEW), Box 25, North Campus, Winneba, Ghana.

SN Applied Sciences (2019) 1:1237 | https://doi.org/10.1007/s42452-019-1273-y 
district in the Upper East region of Ghana is not an exception in grappling with this issue. Recent years have seen an upsurge in concern for waste management, especially in the district capital, Bongo. Based on the population of 84,545 in the district and an average daily waste per capita of $0.45 \mathrm{~kg}$ [8], the district generates $\sim 38.1$ metric tonnes of waste per day. The governmental policy directive is for districts in Ghana, including the Bongo district, to identify areas suitable for landfill sites and acquire those lands in far advance of development activities. However, the selection of a site for developing a landfill, taking into account environmental, engineering, social, political and economic factors, is one of the most important decisions to make in executing the district's waste management responsibility [9]. A poorly chosen site is likely to be associated with high costs of waste transport, site development and operations, or environmental protection. It may also cause sociopolitical problems arising from public opposition. Conversely, a well-chosen site may enable waste disposal without significant damage to the environment and minimal investment. It can also resolve the impasse in landfill siting such as nimby (Not In My Backyard), nimn (Not in My Neighbourhood) and banana (Build Absolutely Nothing Anywhere Near Anyone).

Thus, many factors and constraints must be incorporated in order to select a suitable landfill site. This makes the selection process complex and daunting [10] and also time-consuming. As a result, the computer-based geographic information systems (GIS) approach has been used to facilitate the process. The approach has been used to address conflicting criteria for suitable site selection [11]. This is because this approach has high ability to manage large volumes of spatial data and stimulate necessary factors from a variety of sources $[2,7,10,12]$. A number of researches have been done on landfill site selection using GIS. For instance, Chabuk et al. [12] used GIS in combination with Analytical Hierarchy Process (AHP) and Simple Additive Weighting (SAW) method for selecting suitable landfill sites in Al-Musayiab Qadhaa, Iraq. The results of the two methods were compared to select the most suitable site. The AHP has also been used to weight criteria in GIS-based environment to generate suitable landfill site selection in Senirkent-Uluborlu, Turkey [10]. Also, Vosoogh et al. [13] used GIS to assess existing landfill sites as well as determine new sites in Mashhad city. GIS has also been used to identify suitable landfill site in Leh district in the Trans-Himalayas Region [14]. However, this study focused mainly on technical and engineering criteria much so to the neglect of the sociocultural criteria. On the other hand, the technocratic and indigenous knowledge has also been used in GIS to map suitable landfill sites [7]. Thus, GIS is essential in analysing parameters and providing mathematical computations on landfill suitability.
The criteria for selecting suitable landfill sites are themselves subject to prioritisation according to the local environmental, social, political, economic, physical and engineering considerations [9]. Such prioritisation of factors is so important in a suitability analysis such as landfill siting. Therefore, site selection based on criteria selection and prioritisation from different stakeholders and administrative levels may influence the suitability of areas for landfills. However, research into how criteria selection and prioritisation influence outcomes in a GIS-based landfill site selection is scarce. The exception is Kursah [7] who identified landfill sites based on two different stakeholders, the local technocrats and the indigenes. However, the study did not include criteria selection and prioritisation by governmental guidelines, which is most important, and in the case of Ghana overrules the other two stakeholders. This is because the guideline is the only documented and legally binding policy on the issue. Thus, this study generated landfill suitability maps using criteria selection and prioritisation by the (1) governmental guideline [5], (2) the local technocrats and (3) the indigenes. Two optimal suitability maps-(4) the local optimal involving criteria harmonisation of the two local stakeholders (local technocrats and the indigenes) and (5) the global optimal (integration of the two local stakeholders and the governmental guideline)-are also produced. The results of the five suitability maps are compared using the error index technique proposed by Carrara et al. [15]. Bongo district was chosen for this study because of the fast-growing population and the availability of large virgin lands that makes criteria selection less complex. Also, securing such lands for future use is easier.

\section{The study area}

The Bongo district (Fig. 1) is located in the Upper East region of Ghana, West Africa. The district lies between latitudes $10^{\circ} 49^{\prime} 00^{\prime \prime}$ and $11^{\circ} 00^{\prime} 00^{\prime \prime} \mathrm{N}$ and longitudes $0^{\circ} 37^{\prime} 00^{\prime \prime}$ and $0^{\circ} 57^{\prime} 00^{\prime \prime} \mathrm{W}$. The northern boundary of the district is the border between Ghana and the Republic of Burkina Faso. The district covers about $460 \mathrm{~km}^{2}$. The farthest north-south and the east-west distances are about $19 \mathrm{~km}$ and $33 \mathrm{~km}$, respectively. The last population and housing census in 2010 showed that there were 84,545 inhabitants in the district, an increase of about $9 \%$ from the previous census in 2000 [8]. This increase has resulted in the critical need for a landfill site for the management of waste in the district.

The district is located in the dry savannah area. Annual rainfall ranges from $600 \mathrm{~mm}$ to a little over $1000 \mathrm{~mm}$. Generally, the area has sparse vegetation with a few isolated dry resistant trees. A landfill siting should, therefore, 


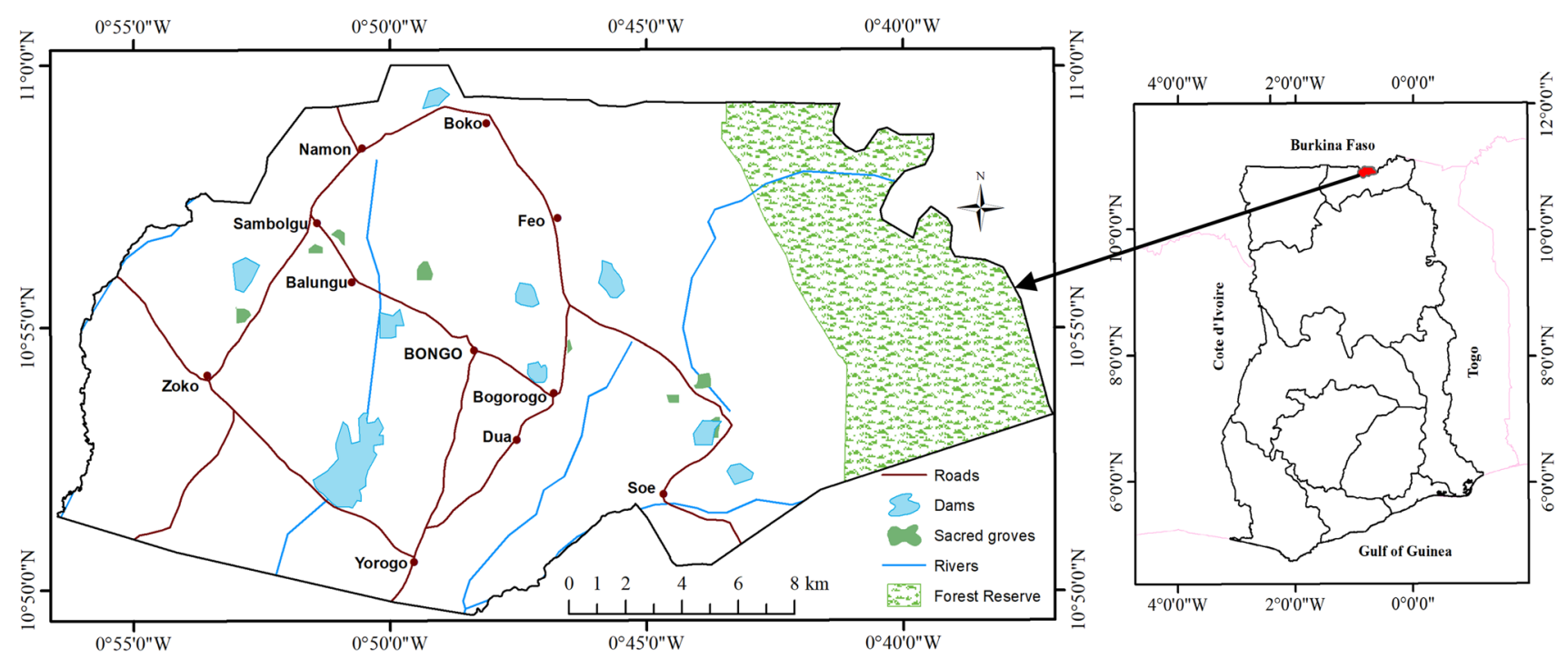

Fig. 1 Map of Bongo district

consider vegetation cover so that the few forest cover is not further destroyed. There is the Asolimpiiro forest reserve at the eastern part of the district. Majority of the inhabitants are peasant farmers where $72.6 \%$ are into agriculture [8]. Due to less rainfall amount, dams have been constructed both as sources of domestic water supply and for irrigation. The most popular and biggest of such dams is the Vea, located south-west of Bongo (the district capital). There are isolated and tiny forest groves in the district, many of which are highly regarded by the indigenes as dwelling places for their gods and ancestral spirits [16]. These traditional worshippers constitute almost half of the population in the district [8]. The terrain in the district is generally flat with few isolated heights ranging between 160 and $370 \mathrm{~m}$.

\section{Criteria and prioritisation for landfill selection}

\subsection{Criteria selection and prioritisation in the governmental guidelines}

The governmental landfill guideline [5] was formulated in May 2002. The guideline is to provide the basis upon which the Environmental Protection Agency (EPA) will issue environmental permits and certificates for landfill operations. It also forms the basis upon which the permit for landfill operations is renewed. These criteria represent enforceable standards. Though highly scattered in the guideline document, the criteria (both factors and constraints), the prioritisation and the rationale are extracted and listed in Table 1. The guideline identified two kinds of criteria, factors and constraints [5]. The factors are continuous in nature. It enhances/reduces how suitable an area is for a landfill site. On the other hand, constraints are areas where the siting of a landfill would be obnoxious due to the volatility of the area, regulation or the sensitivity of the area. Constraints are, therefore, Boolean in nature and turn to exclude specific areas that have been considered for landfill siting. Literature supports the guideline's categorisation and has concluded that a good landfill site selection must include the two sets of criteria $[2,5,10,17]$. These criteria are meant to avoid the health and the environmental risks, especially leachate, posed by landfills. However, some of the criteria may not be applicable to all locations. For instance, only four factors involving slope, water bodies, properties and distance to roads have been used to identify a suitable landfill site in Sekondi-Takoradi, Ghana [2]. On the other hand, a constraint such as distance beyond $30 \mathrm{~km}$ to the source of waste due to transport cost is not applicable in the study area since the farthest north-south and the east-west distances are about $19 \mathrm{~km}$ and $33 \mathrm{~km}$, respectively. Moreover, due to communal land ownership system in the district, land purchase cost is not applicable. A constraint of at least $2 \mathrm{~m}$ above groundwater table was not included in this study due to unavailability of such data in the district. However, the qualitative information about this factor does not lend credence to support that this will be a serious problem in the district.

\subsection{Criteria selection and prioritisation by the local technocrats}

For criteria selection and prioritisation under this, 15 local technocrats which included civil engineers, planners and 
Table 1 The criteria and the rationale in the governmental landfill guideline

\begin{tabular}{|c|c|c|}
\hline Factors & Rationale & $\begin{array}{l}\text { Applicable to } \\
\text { the study area }\end{array}$ \\
\hline \multicolumn{3}{|l|}{ Engineering } \\
\hline Soils & $\begin{array}{l}\text { Maximise soils which are easy for construction and as cover mate- } \\
\text { rials for operation and control of nuisances }\end{array}$ & Yes \\
\hline Elevation & Avoid low-lying, floodable and the extreme high areas & Yes \\
\hline Slope & Maximise gentle and even slopes & Yes \\
\hline \multicolumn{3}{|l|}{ Environmental } \\
\hline Watercourses & Avoid surface water contamination & Yes \\
\hline Sensitive ecological sites, e.g. wetlands & Protect ecological areas and prevent contamination & No \\
\hline \multicolumn{3}{|l|}{ Economic } \\
\hline Distance to roads & Distance to transport routes and access to the site & Yes \\
\hline Distance to residential areas & Minimise transport cost for waste transport & Yes \\
\hline Land acquisition cost & Maximise low-cost lands & No \\
\hline \multicolumn{3}{|l|}{ Sociopolitical } \\
\hline Out of sight from settlements and roads & Reduce the need for screening and public acceptance & Yes \\
\hline Proximity to airports & Safety: to prevent clashes of planes and birds & No \\
\hline \multicolumn{3}{|l|}{ Constraints } \\
\hline Avoid slopes $>10^{\circ}$ & Avoid steep slopes or maximise gentle slopes & Yes \\
\hline \multicolumn{3}{|l|}{ Environmental } \\
\hline $300 \mathrm{~m}$ from ponds/lakes/dams & Avoid water contamination & Yes \\
\hline $90 \mathrm{~m}$ from rivers & Avoid water contamination & Yes \\
\hline Avoid nature reserves & Protect the ecosystems in the reserves & Yes \\
\hline $360 \mathrm{~m}$ from a well & Avoid water contamination & No \\
\hline $2 \mathrm{~m}$ to the groundwater table & Avoid groundwater contamination & No \\
\hline \multicolumn{3}{|l|}{ Economic } \\
\hline$>30 \mathrm{~km}$ to the main source of waste & Maximise cost of transporting waste & No \\
\hline \multicolumn{3}{|l|}{ Consequential } \\
\hline $50 \mathrm{~m}$ from powerlines & Provide safety of the sites & Yes \\
\hline Avoid displacement of inhabitants & Avoid compensation cost and public resistance & Yes \\
\hline Avoid water pipelines & Avoid cost in pipeline relocation and water disruption & No \\
\hline $3000 \mathrm{~m}$ to end of the airport runway & For safety-to prevent clashes of planes and birds & No \\
\hline $500 \mathrm{~m}$ to the military exclusion zone & For safety and legal restrictions & No \\
\hline $500 \mathrm{~m}$ from airfield or airport & Safety: prevent clashes of planes and birds & No \\
\hline Fault/seismic zones/mining pits & To avoid subsidence & No \\
\hline \multicolumn{3}{|l|}{ Sociopolitical } \\
\hline $500 \mathrm{~m}$ from historical sites & Avoid public resistance and preserve artefacts & No \\
\hline $500 \mathrm{~m}$ from roads & Kept out of sight from people and for aesthetic reason & Yes \\
\hline $500 \mathrm{~m}$ to residential areas & Aesthetic, avoid odour and health implications & Yes \\
\hline
\end{tabular}

the Environmental Officer in the district were purposively sampled to identify criteria they will consider in siting a landfill and to prioritise these criteria based on their degree of influence. The criteria identified were twofold: the factors and the constraints (Table 2). This is in conformity with the existing literature $[4,10,17,18]$. The local technocrats identified seven factors. These are nearness to watercourses, residential areas and roads, landcover type, soil type, elevation and slope. The mean distance is used for the distance-based criteria. The constraints are forest reserves, specified buffer to roads, residential areas, powerlines and watercourses. They also identified sacred groves as a constraint area.

\subsection{Criteria selection and prioritisation by the indigenes}

Like the local technocrats, 15 indigenes including the chiefs, tindaana (land chief) and opinion leaders in the district were purposively sampled to identify and prioritise 
Table 2 Criteria selection of the local technocrats and the indigenes

\begin{tabular}{|c|c|c|c|}
\hline Factors & Weights (\%) ${ }^{a}$ & Constraints & Buffer (metres) \\
\hline \multicolumn{4}{|l|}{ Local technocrats } \\
\hline Watercourses (rivers and dams) & 16 & Watercourses (rivers and dams) & 800 \\
\hline Residential areas (urban) $)^{b}$ & 13 & Residential areas (urban) ${ }^{b}$ & 750 \\
\hline Residential areas (rural) ${ }^{\mathrm{b}}$ & 13 & Residential areas (rural) ${ }^{b}$ & 550 \\
\hline Roads & 13 & Roads & 500 \\
\hline Landcover & 12 & Powerlines & 100 \\
\hline Soil & 13 & Forest reserve & - \\
\hline Elevation & 17 & Sacred groves & - \\
\hline \multirow[t]{2}{*}{ Slope } & 16 & & \\
\hline & 100 & & \\
\hline \multicolumn{4}{|l|}{ Indigenes } \\
\hline Watercourses (rivers and dams) & 14 & Watercourses (rivers and dams) & 1000 \\
\hline Residential areas (urban) $)^{b}$ & 11 & Residential areas (urban) ${ }^{b}$ & 200 \\
\hline Residential areas (rural) ${ }^{\mathrm{b}}$ & 11 & Residential areas (rural) ${ }^{\mathrm{b}}$ & 150 \\
\hline Roads & 12 & Roads & 500 \\
\hline Landcover & 12 & Powerlines & 240 \\
\hline Soil & 10 & Forest reserve & - \\
\hline Elevation & 12 & Sacred groves & 1200 \\
\hline Sacred groves & 15 & & \\
\hline \multirow[t]{2}{*}{ Slope } & 14 & & \\
\hline & 100 & & \\
\hline
\end{tabular}

${ }^{\mathrm{a}}$ The values are approximated to the nearest whole number

${ }^{b}$ Urban and rural residential areas are a single criterion criteria for a landfill siting. This group of stakeholders also identified two kinds of criteria: the factors and the constraints (Table 2). However, the indigenes identified eight factors. These are nearness to watercourses, residential areas, roads and sacred groves, landcover type, soil type, elevation and slope. Like above, the mean distance is used for the distance-based criteria. The six constraints they identified are forest reserves and buffer to roads, residential areas, powerlines, watercourses and sacred groves. Thus, the indigenes did not only identify sacred groves as a constraint, but they also want a buffer of $1200 \mathrm{~m}$ around it. Within this buffer, the landfill should not be constructed. Also, areas closer to the sacred groves are less suitable for a landfill, while farther areas are suitable. Fundamentally, these are the differences between the local technocrats and the governmental guideline on the one hand and the indigenes on the other. The rationale for including sacred groves also varied among the three stakeholders. For the technocrats and the guideline, the rationale was for scientific basis such as maintaining the tree species, avoiding the cost associated with tree cutting and to maintain the ecosystem. However, the indigenes want to protect the sacred groves because they are places of worship and form part of their embodiment and well-being.

To sum up, the criteria for landfill siting are many and a computer-based GIS approach is one good alternative.
However, the quality of the result is based on the availability of data, data quality, expert knowledge and most importantly, but not frequently mentioned, the prioritisation of the criteria. This is why this study seeks to generate landfill suitability using criteria selection and prioritisation in the governmental guideline and compare it with results of the local technocrats, indigenous and two optimal perspectives.

\section{Methodology}

\subsection{Datasets and the processing of factor maps}

A $30 \mathrm{~m} \times 30 \mathrm{~m}$ SRTM digital elevation model (DEM) (Fig. 2a) was downloaded from USGS/GloVis (https://glovis.usgs. gov/app?fullscreen=0). The slope layer (Fig. 2b) was generated from the DEM using the slope tool in ArcMap 10.3. The soils (Fig. 2c), landcover (Fig. 2d), drainage, roads and settlements datasets were acquired from the Centre for Remote Sensing and Geographic Information Systems (CERGIS) of the University of Ghana. The datasets were coregistered appropriately. The distances to rivers (Fig. 2e), dams (Fig. 2f), residential areas (Fig. 2g), roads (Fig. 2h) and sacred groves (Fig. 2i) were generated using the Euclidian 

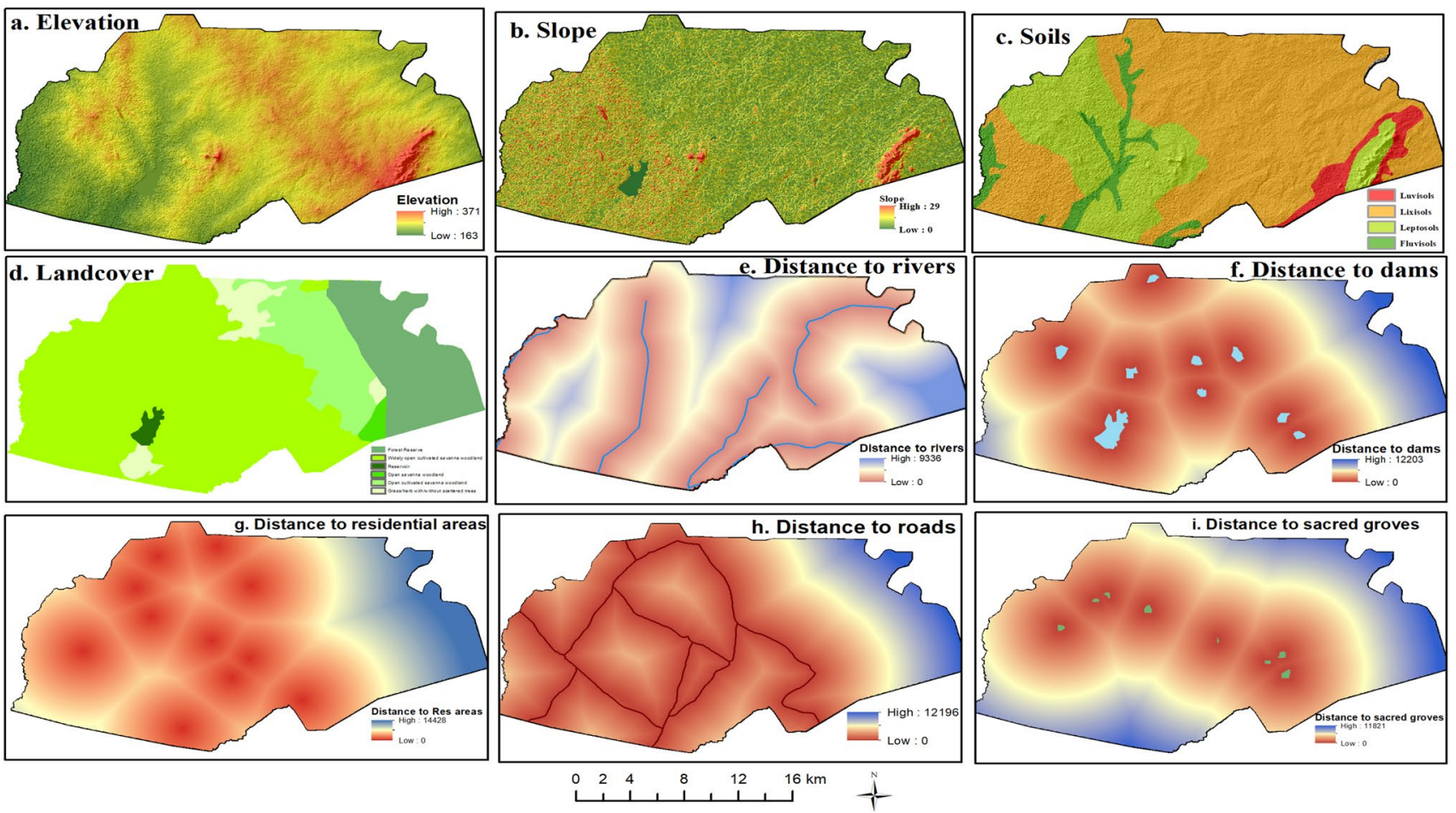

Fig. 2 Landfill factors for suitability mapping. Distances are in metres

distance in ArcMap with $30 \mathrm{~m} \times 30 \mathrm{~m}$ spatial resolution (the same as the DEM).

The individual criterion (Fig. 2) was processed by converting the factors to a similar scale measurement ranging from 0 to 9 , where 0 means not suitable at all and 9 means the most suitable based on the criteria preferences in the governmental guideline, by the local technocrats and the indigenes. The local and global optimal perspectives were also generated. The categorical factors such as landcover and soil types were reclassified into suitability values based on the suitability of the classes to landfill siting as shown in Table 3. The conversion to the same measurement scale generated suitability values for the different criteria.

\subsection{Constraint maps}

The constraints and the dimension identified in the governmental guideline and by the local technocrats and the indigenes were used to create constraint maps for each perspective using the buffer tool. Rivers and dams serve as major water sources in the district, and the buffer is to avoid contaminating these sources. Buffers to residential areas, roads and the powerlines are to avoid exposure to people and avoid health complications and stench that
Table 3 The suitability values for the landcover and the soil types

\begin{tabular}{lll}
\hline Factor & Classes & Suitable value \\
\hline Landcover & Grass/herb with/without scattered trees (0-5 trees/ha) & 9 \\
& Widely open cultivated savannah woodland (6-10 trees/ha) & 7 \\
& Open cultivated savannah woodland (11-20 trees/ha) & 4 \\
& Open savannah woodland (<25 trees/ha) & 1 \\
& Built-up area & Restricted \\
& Reservoir & Restricted \\
& Leptosols & 8 \\
Soil & Luvisols & 5 \\
& Lixisols & 3 \\
& Fluvisols & 1 \\
\hline
\end{tabular}


may emanate from the landfill site and electrical accidents, respectively. For the sacred groves, the indigenes believe a 1200-m buffer will protect the peace of the gods and prevent noise that may emanate from waste disposal trucks and waste processing machines. The pixels within the buffers were then reclassified to restricted, meaning these pixels are not considered for landfill siting. For the governmental guideline and the technocratic perspectives, however, only the pixels containing the sacred groves were reclassified as restricted. The overlay tool and the "OR" operator were used to combine the individual constraint maps into one composite map for each perspective showing the exclusionary areas. Constraints by the local technocrats and the indigenes were harmonised by considering the largest extent to generate a constraint map for the local optimal perspective. Likewise, a constraint map of the global optimal perspective was developed by harmonising the constraints dimensions by the local technocrats, the indigenes and the governmental guideline.

\subsection{Suitability mapping}

The landfill factors were combined through the weighted overlay tool in ArcMap to generate landfill suitability index (SI) map using Eq 1.

$\mathrm{SI}=\sum W_{i} X_{i}$

where SI represents the suitability index, $w_{i}$ represents the weight of criterion $i$, and $x_{i}$ represents the standardised score from 0 to 9 of criterion $i$. The suitability index generated ranged from 0 to 7 due to the trade-off of factors-a feature that makes the weighted overlay tool powerful for suitability analysis $[19,20]$. The isolated suitable areas less than 9 hectares $\left(90,000 \mathrm{~m}^{2}\right)$ continuous pixels were eliminated using Region group, Set Null and Nibble tools since these are below the minimum threshold landmass for a landfill in the area.

\subsection{Combining factor and constraint maps}

The output of the SI map was combined with the constraint maps of Boolean logic using Eq 2. This allows the removal of all areas specified as unsuitable for a landfill site due to its fragility, environmental protection or health implications.

$S_{\text {Map }}=\sum W_{i} X_{i} \times \Pi C_{j}$

where $S_{\text {Map }}$ represents the suitability map, $C_{j}$ represents the score of constraint $j$, and $\Pi$ represents the product sign for the constraints. This implies that the product of the constraint was multiplied by the suitability index of each pixel. The suitability map was reclassified into three levels using the same scale range as in Kursah [7] -highly suitable $(\geq 6)$, moderately suitable $(\geq 5)$ and less suitable $(>4)$.

\subsection{Comparison of the landfill suitability maps}

The comparison of the landfill suitability maps of the different perspectives was made using the error index technique proposed by Carrara et al. [15]. The error index (degree of matching) quantifies the geographical discrepancy between the results of the different perspectives. The error index, $E$, is calculated as in Eq 3.

$E=\frac{\left(S_{u} \cup V_{i}\right)-\left(S_{u} \cap V_{i}\right)}{\left(S_{u} \cup V_{i}\right)} \quad 0 \leq E \leq 1$

where $S_{u}$ and $V_{i}$ are any two suitability maps to be compared, example highly suitable class from the governmental guideline and the local technocrats. The $\cup$ and $\cap$ are the union and intersection operators. From an $E$ value, the degree of matching, $M$, between the two classes is determined as in Eq 4. An error index closer to 1 indicates that the two classes have a strong overlap, whereas a value closer to 0 shows that the two classes are weakly overlapping or most of it are located at different locations.

$M=1-E \quad 0 \leq M \leq 1$

\section{Results}

The results of the landfill suitability maps from the five perspectives are presented and compared in this section.

\subsection{Landfill suitability maps}

Figures 3, 4, 5, 6 and 7 show the highly suitable (green), moderately suitable (yellow), less suitable (red) and restricted (white) areas for a landfill site in the district derived using criteria selection and prioritisation from the governmental guideline, the local technocrats, the indigenes and the two optimal perspectives. All five perspectives acknowledged the importance of environmental protection such as the forest reserve in the area and have thus constrained those areas. Thus, the eastern part of the district harbouring the Asolimpiiro Forest Reserve is restricted in all the suitability maps. The stakeholders also recognised the importance of protecting the water bodies such as dams and rivers, albeit with varying buffer dimensions. The health and the aesthetic (keeping out of sight) implications of a landfill have also been recognised by the perspectives. Thus, a buffer to residential areas and roads was stated, albeit with varying dimensions. In a whole, all perspectives seek to promote environmental quality and 


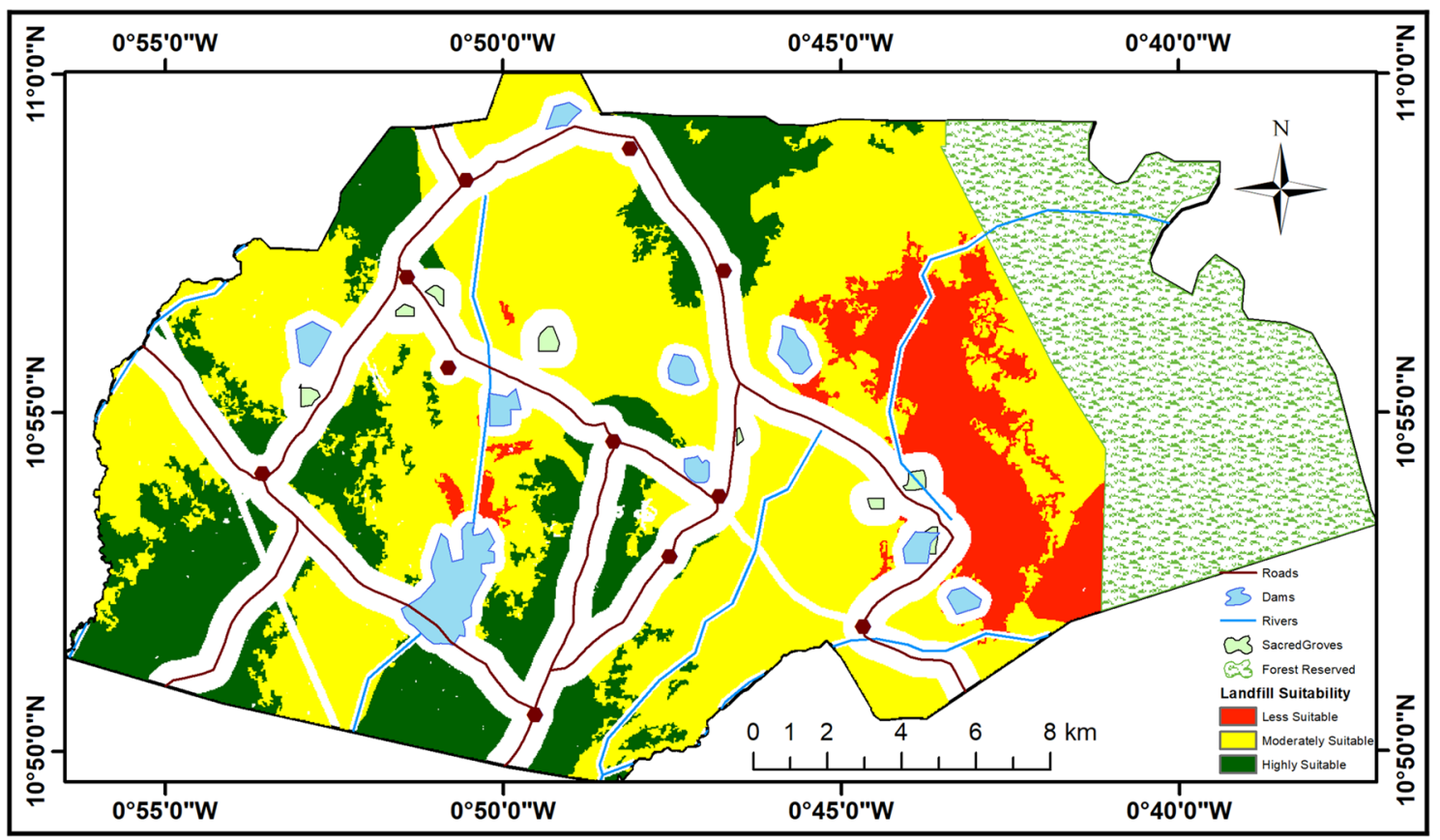

Fig. 3 Landfill suitability based on the governmental policy guideline

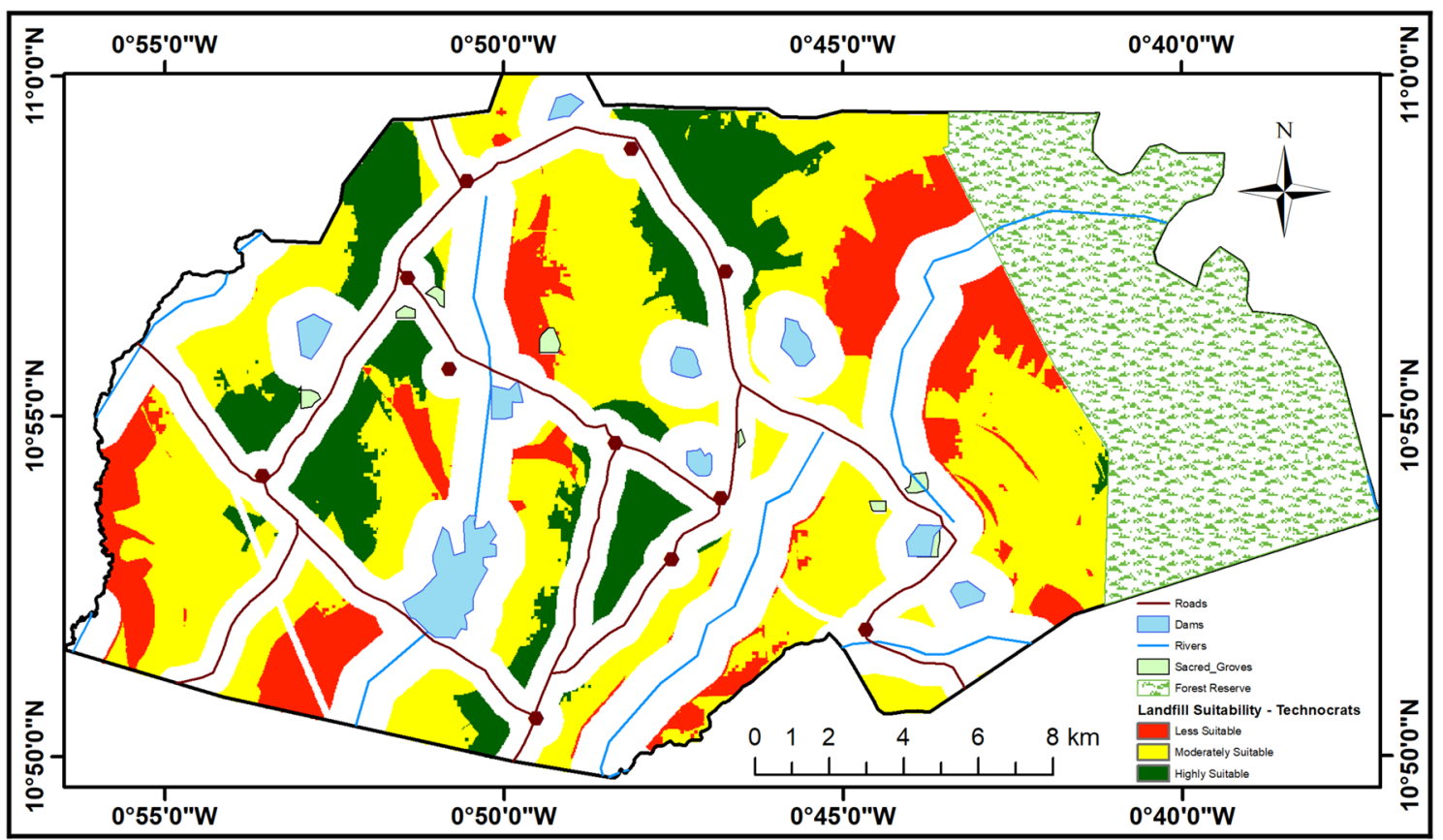

Fig. 4 Landfill suitability based on the local technocrats' perspective

preservation and good health. However, there are salient differences among these perspectives which have caused spatial discrepancies among the suitability maps. Such differences, if not addressed, could be a potential cause of nimby, nimn and banana effects against landfill siting in the district.

Figure 3 shows the landfill suitability map using criteria from the governmental guideline. The guideline was developed at the national level, and it is the only 


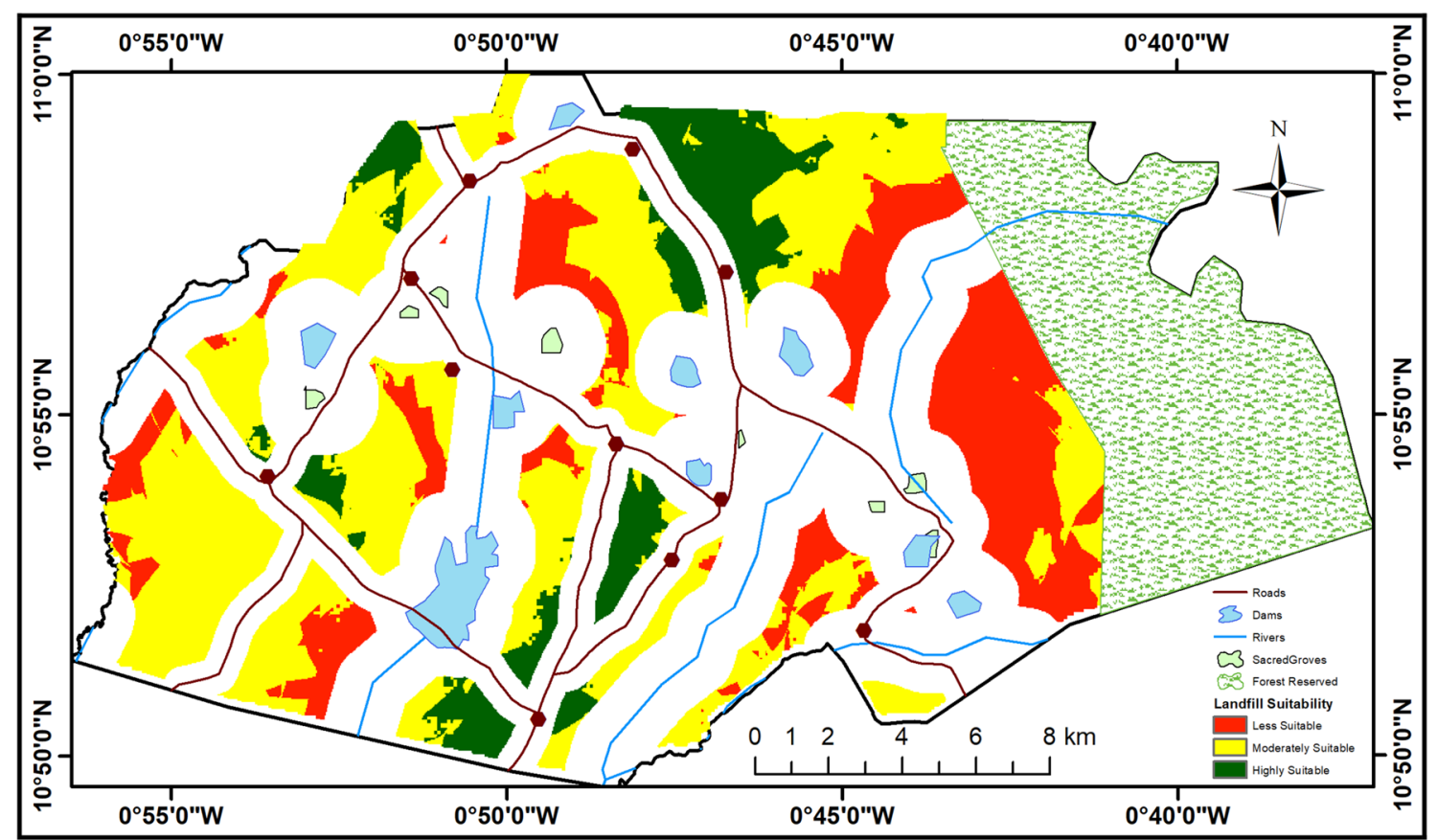

Fig. 5 Landfill suitability based on the indigenes' perspective

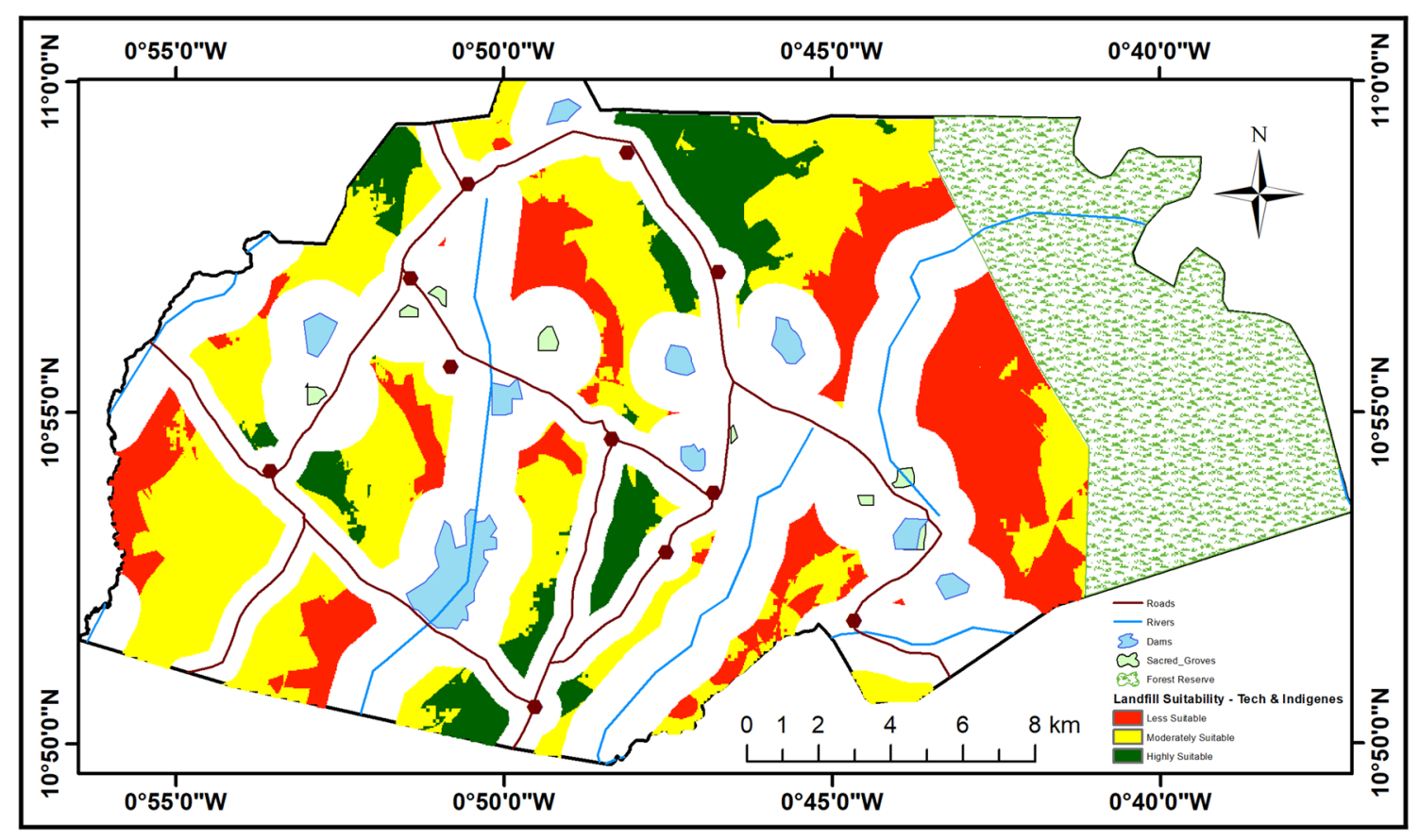

Fig. 6 Landfill suitability based on the local optimal (the technocrats and the indigenes) perspective

documented and perhaps the legally presentable guide in the resolution of conflict arising from landfill siting. It is also the document through which permits for landfill siting are approved and renewed. Table 4 shows that for this perspective, $14.88 \%$ of the district is classified as highly suitable for landfill siting, $35.38 \%$ as moderately suitable, and $7.03 \%$ as less suitable, implying that $57.29 \%$ of the district is classified within the three levels of suitability. Thus, over $42 \%$ of the district is a constrained area. 


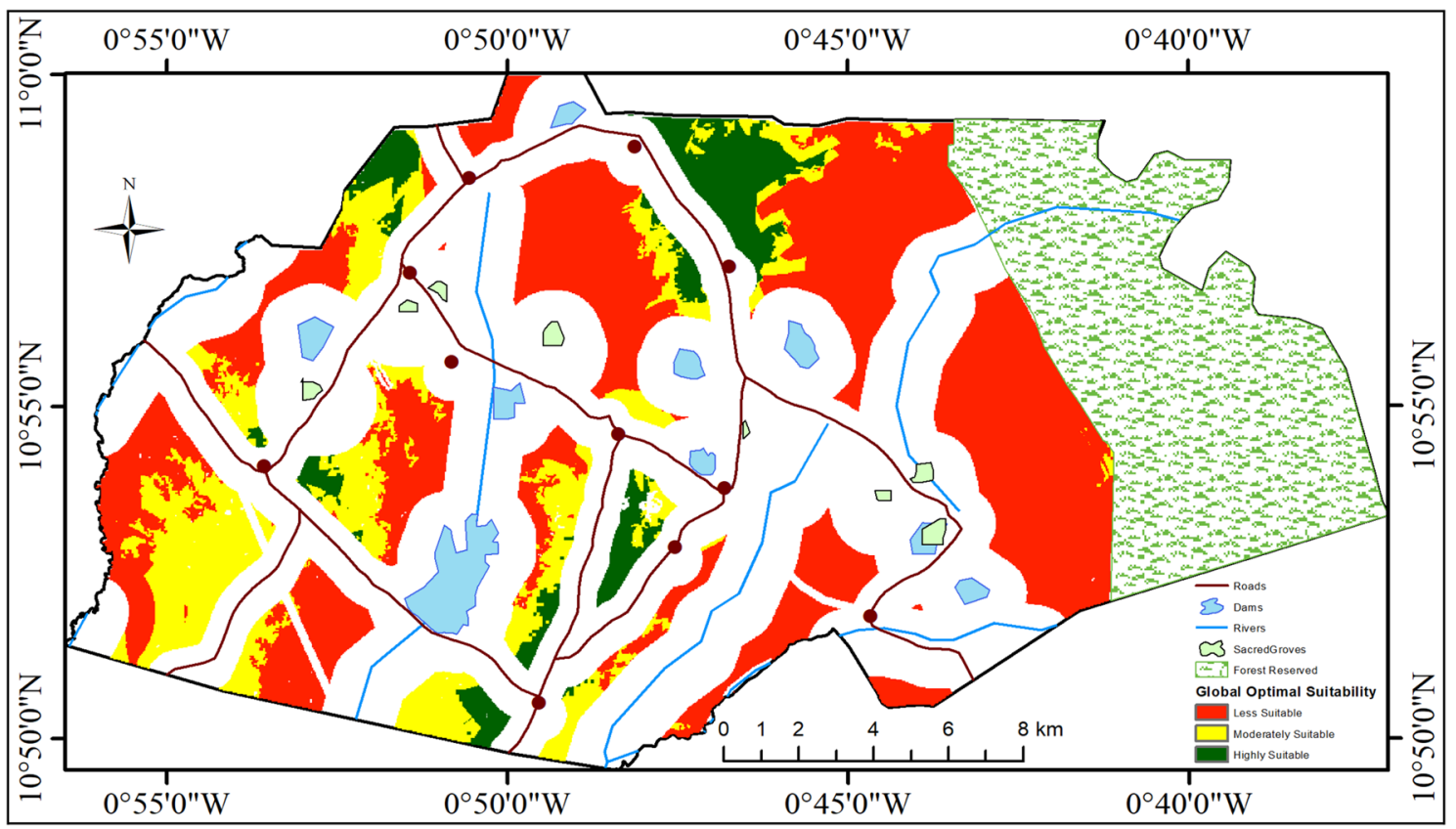

Fig. 7 Landfill suitability based on the global optimal (the guideline, technocrats and the indigenes) perspective

Table 4 The suitability areas for the five perspectives

\begin{tabular}{|c|c|c|c|c|c|c|c|c|}
\hline \multirow{2}{*}{$\begin{array}{l}\text { Suitability } \\
\text { Perspectives }\end{array}$} & \multicolumn{2}{|c|}{ Highly suitable } & \multicolumn{2}{|c|}{$\begin{array}{l}\text { Moderately suit- } \\
\text { able }\end{array}$} & \multicolumn{2}{|c|}{ Less suitable } & \multicolumn{2}{|c|}{ All three classes } \\
\hline & Area* & $\%$ & Area* & $\%$ & Area* & $\%$ & Area* & $\%$ \\
\hline Governmental guideline & 6872.1 & 14.88 & $16,341.6$ & 35.38 & 3247.4 & 7.03 & $26,461.0$ & 57.29 \\
\hline Local technocrats & 4150.7 & 8.99 & $12,221.9$ & 26.46 & 3951.6 & 8.56 & $20,324.2$ & 44.01 \\
\hline Indigenes & 2582.1 & 5.59 & 9570.1 & 20.72 & 4919.9 & 10.65 & $17,072.0$ & 36.97 \\
\hline Local optimal & 2616.5 & 5.67 & 8977.1 & 19.44 & 5243.3 & 11.35 & $16,837.0$ & 36.46 \\
\hline Global optimal & 1645.1 & 3.56 & 3936.3 & 8.52 & $10,110.0$ & 21.89 & $15,691.3$ & 33.98 \\
\hline Total area of the district ${ }^{\mathrm{a}}$ & $46,184.3$ & & & & & & & \\
\hline
\end{tabular}

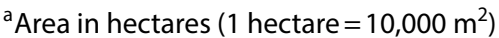

Figure 4 shows the landfill suitability map derived using criteria selection and prioritisation from the local technocrats in the district. These local technocrats are expected to have in-depth knowledge about the district than those at the national level who designed the governmental guideline. It is not surprising that their criteria selection resulted in reduced areas classified as highly suitable for a landfill. Table 4 shows that only $\sim 9 \%$ of the area of the district is classified as highly suitable for a landfill site, $26.5 \%$ as moderately suitable, and $8.6 \%$ as less suitable. In all, $44 \%$ of the district is classified within the three levels of suitability, indicating that $\sim 56 \%$ is constrained for a landfill site due to the fragility of the area or environmental quality or health reasons.

Figure 5 shows the landfill suitability map derived using prioritisation of criteria from the indigenes in the district. The indigenes are major stakeholders and the main beneficiaries of the landfill site and, consequently, a cleaner environment. It is also hoped that the indigenes may hold some sociocultural beliefs inherent in superstitions and traditions about the area. Therefore, their criteria selection and prioritisation included those social norms. As such, this perspective produced a much-reduced area (5.6\%) classified as highly suitable for a landfill site, mainly because they are also the very people at risk of the negative externalities from the landfill. Also, $20.7 \%$ is classified as moderately suitable and $10.7 \%$ as less suitable (Table 4 ). The entire area within the three levels of suitability has also reduced to $37 \%$, indicating $63 \%$ of the entire district is constrained.

Figure 6 shows the suitability map derived from the local optimal perspective. It is referred to as the local because it involved the harmonisation of criteria from the local technocrats and the indigenes (stakeholders at the 
local level). This produced suitability that avoided the challenges embedded in the technocratic and the indigenous perspectives, especially criteria related to social norms and closeness to residential areas. For this perspective, only $5.7 \%$ is classified as highly suitable, $19.4 \%$ as moderately suitable, and $11.4 \%$ as less suitable (Table 4 ). In all, $36.5 \%$ of the district is classified within the three levels of suitability, indicating $63.5 \%$ are constrained areas.

Figure 7 shows the suitability map derived from the global optimal perspective. It is referred to as the global, albeit vaguely because it involved the harmonisation of criteria from both the local stakeholders and the "external" power (national authorities). For this perspective, only $3.56 \%$ of the district is classified as highly suitable, $8.52 \%$ as moderately suitable, and $21.89 \%$ as less suitable areas (Table 4). In all, $33.98 \%$ of the district is classified within the three levels of suitability, indicating $66.02 \%$ are constrained areas.

\subsection{Comparison of the landfill suitability from the different perspectives}

Table 5 shows the overall error index matrix of the highly suitable landfill siting for the five perspectives. The error index shows the degree to which suitability classes of any two perspectives overlap. The results generally show low error index (degree of matching) between the highly suitable class of the governmental guideline and the rest of the perspectives. However, some differences and trends exist. The governmental guideline's perspective lowly overlaps (0.340) with the indigenous perspective more than it does with the local technocrats' (0.496) perspective. On the other hand, the indexes show an average to high spatial overlap between the local technocrats, the indigenes and the two optimal perspectives. The indigenous perspective overlaps much stronger $(0.583)$ with the local technocrats' perspective than it does with the governmental guideline's $(0.340)$ perspective. There is an improvement in overlapping $(0.619)$ between the local optimal and the local technocrats' perspectives and even

Table 5 Error index matrix of the highly suitable landfill siting for the different perspectives

\begin{tabular}{llllll}
\hline Perspective & GG & LT & I & LO & GO \\
\hline GG & 1 & & & & \\
LT & 0.496 & 1 & & & \\
I & 0.340 & 0.583 & 1 & & \\
LO & 0.353 & 0.619 & 0.938 & 1 & \\
GO & 0.313 & 0.536 & 0.752 & 0.718 & 1 \\
\hline
\end{tabular}

GG governmental guideline, $L T$ local technocrats, I indigenes, $L O$ local optimal, GO global optimal more (0.938) with the indigenous perspective. The local optimal suitability map overlaps much stronger with the indigenous perspectives and thus has a better potential to avoid local opposition in the form of nimby and nimn than the global optimal (0.752) perspective. Thus, criteria selection and prioritisation at the local levels are more similar than those at the national level.

\section{Discussions}

The study aimed at generating suitable landfill sites in the Bongo district of Upper East region, Ghana, using criteria and prioritisation provided in the governmental guideline [5], the local technocrats and the indigenes. Two optimal perspectives were also generated, comprising the harmonisation of criteria by the local technocrats and the indigenes (the local optimal) and all three stakeholders (the global optimal). A number of similar criteria are contained in the governmental guideline document and enumerated by the local technocrats and the indigenes. However, the prioritisation and dimension of constraint areas for these criteria differ to a large extent between the three sets of stakeholders. The guideline and the local technocrats' perspectives require that the pixels containing the sacred groves be restricted from being considered for a landfill site. The indigenes, however, added a buffer of $1200 \mathrm{~m}$. This is a potential source of opposition by the local people if the guideline or the local technocrats are solely relied upon the landfill siting process. The indigenes also want that after the $1200 \mathrm{~m}$ buffer, the farther the landfill to the sacred groves, the better-making sacred groves a factor as well.

Governmental guideline's perspective produced not only the largest areas classified as highly suitable, but it also had the largest areas classified within the three levels of suitability. There is a high spatial discrepancy of landfill suitability between this perspective and the rest of the other perspectives. This is not surprising as the governmental guideline was designed at the national level with no input from the local level and the indigenes. As such, much emphasis and constraints have not been assigned to some sociocultural factors and constraints. While the criteria in the guidelines ordinarily are to show the minimum threshold standards, it is the only documented and enforceable guide in any legal context or conflict resolution. This has been worsened by the fact that the issuance of the permits for such infrastructure has often been taken at the level beyond the reach of the indigenes based on this guideline. This explains why spontaneous agitations or demonstrations against landfill siting without initial logging of complaints are common. The indigenes usually know the project proponent(s) have already secured 
the permit "legally", and there is no need for any official complains which in their view will not even be looked at. In cases where the local residents are said to be involved or participated, it is done selectively or too late and the local people are rather told to accept it with the emphasis on the benefits of the infrastructure such as job creation and income generation. The local residents are at best uninfluential participants in such stakeholders' consultation, which should better be termed as "informing" rather than consultation. Major defects of the guidelines include: firstly, the stipulated buffers such as $90 \mathrm{~m}$ to rivers, $300 \mathrm{~m}$ to ponds, lakes, surface water and dams, and $360 \mathrm{~m}$ to wells in current use are too compromising and not acceptable, especially with the poor maintenance culture concerning landfilling, waste dumping and waste management in the country. Secondly, constraint buffer of $500 \mathrm{~m}$ for residential areas is too small as such buffer will quickly be "swallowed" up with the fast urban sprawling witnessed in the area and in Ghana in general. A wider dimension for both urban and rural areas is therefore suggested. Thirdly, the protected areas are only considered a constraint and not as a factor-the farther the better for a landfill. Fourthly, keeping landfill out of sight gave too little buffer to roads and did not mention tourist sites as well. This is against a governmental policy to re-vitalise tourism activities in that part of the country, indicating the guideline was designed without situating it into the other sectoral policies and guidelines. Fifthly, the guideline does not enjoin project proponents to consider past demographic growth rates in order to avoid oversizing the landfill facility with only the current census figures. This defect may have been due to the fact that the country has had irregular census in the past in 1984, 2000 and 2010only three censuses since the 1970 s. Another reason could be the generally poor planning and modelling or proactive attitudes towards addressing problems in the country. Studies on landfill siting in Ghana $[2,7]$ and elsewhere $[9$, 21,22 have shown that the standards set in the governmental guideline are inadequate to achieve environmental and health quality or prevent the issue of nimby, nimn and banana syndrome. It is not surprising that this phenomenon is common and widespread in the country [23,24], especially against landfill siting.

The landfill suitability maps from the perspective of the local technocrats produced the second-largest areas classified as highly suitable. The shortcoming of this perspective is it over-reliance on the technical feasibility of landfill siting and less emphasis on the sociocultural factors such as sacred groves and cultural belief and practices. Thus, this perspective produced areas which are classified as highly suitable for a landfill at the north-western part of the district, which is very close or surrounds three important sacred groves. Constructing a landfill site in such an area would not only be seen as sacrilege, but it will also be resisted fiercely by the local people. Such kind of resistance in the district and other parts in Ghana and Asia has been reported [7, 16, 23-25]. The study concurs with Macharia and Mundia [26] and Kursah [7] that while it is difficult to do away with social norms and practices of the local people, the technical and engineering concerns on landfill siting can be mitigated through engineering works and technology. The overall error index shows that this perspective produced a suitability map much similar to the one from the governmental guideline. This is not surprising, as these technocrats more or less passed through the same educational system grounded in western values and belief systems that often see indigenous belief systems and practices including the sacred groves as primitive and unscientific and not worth exploring or recognition. In many occasions, such sociocultural and religious values are seen as an obstacle to modernity that must be eliminated $[7,27,28]$. On the contrary, a study has revealed that indigenes were more willing to have a landfill located closer to watercourses and houses than to the sacred groves since they believe those are the abode of their gods [7]. Thus, any landfill siting that compromises these social norms and practices will meet fierce opposition from the indigenes.

The landfill suitability map generated with the criteria selection and prioritisation from the indigenes is much in agreement with the local aspirations as it preserved the most important things they care much about-the social norms and practices enshrined in the sacred groves which harbour the Tingaane (earth shrines). The buffer around the sacred groves and the forest for sociocultural and ecological purposes was more important criterion for the indigenes than for the governmental guideline and the local technocrats. This differs from the study by Dar et al. [14] which principally used technical, engineering and financial criteria. However, the finding concurs with Macharia and Mundia [26] who found that higher weights were assigned to environment and social criteria than to engineering and technical criteria in suitability analysis in Kenya, Africa. This is explained by the fact that the indigenes who are mainly peasant farmers and hunters are still attached to nature than the elite society who mainly formed the technocrats - at both the national and the local levels. Thus, it will be in order to infer that the indigenes in the district are more environmentally friendly and protective of the environment than the technocrats. However, as has been concluded by other studies $[7,16,28,29]$, the protection of the forest and groves may not be purely due to the ecological purposes, but the belief that those areas are the abode of the gods and the ancestral spirits. There is also an argument that the rationale of this belief system is merely 
the traditional way of protecting the ecosystem. Whichever way this is viewed, the indigenes had a higher priority for environmental protection than the other perspectives.

The local optimal perspective combined the local technocrats and the indigenous perspectives to produce an optimal landfill site. This produced a smaller area classified as highly suitable. The global optimal combined all three sets of stakeholders' perspectives to produce an even smaller area suitable for a landfill. Therefore, the harmonisation of the other perspectives makes these two a better option for landfill siting. Even though the suitability maps of the local optimal and the global optimal overlap strongly with the indigenous and local technocrats' perspectives, it appears that the former is more overlapping and fulfils both the aspirations of the indigenes while addressing the technical and engineering concerns. Thus, the local optimal perspective is recommended over the other perspectives. Nevertheless, the participation of all the stakeholders, especially at the local level, in a mutual dialogue will result in a better criteria selection and prioritisation and design of a guideline that will resolve the potential conflicts arising in a landfill siting.

In general, the error index results show a high spatial agreement between the suitability classes from the different perspectives except for the governmental guideline. Most of the error indexes were above 0.30 which has been defined to indicate a significant discrepancy [30]. However, the criteria selection and prioritisation at the local levels are more similar than those at the national level. It means that project proponents could easily meet the requirements of the governmental guideline, but the site could still be socially destructive to the local residents. This could be the source of impasse and local opposition should the guideline be, as the policy directs, the basis for issuing permits for landfill sites in the district. Another source of the agitations by the local residents may arise from the compromising nature of the guideline, especially concerning constraint buffers on social and environmental values of the indigenes. Moreover, a guideline designed at the national level but binding on the local level without the latter inputs is bound to face such oppositions. In this regard, it is recommended that the district, and by implications, all districts in the country, be assisted to design their own landfill guidelines that are unique and appropriate to the locality. Such unique district guideline should take preference over those from the higher level. The results in this study concur with the existing literature that showed the superiority of GIS-based multicriteria approach for site selection $[9,21,22]$. This superiority of the approach is not limited to landfill siting alone but also for infrastructure such as electric vehicle charging stations [31], bike-share stations [11] and potential ecotourism sites [32]. The number of criteria included in the study and the use of deterministic parameters that may not necessarily cope with uncertainty are the main limitations of this study. Therefore, it is recommended that an environmental impact assessment (EIA) be conducted by the District Assembly (DA), the environmental and the planning departments of the district on the specific site(s) chosen within the highly suitable areas to ascertain its full environmental and social impact.

The health and living conditions of the people will be better when wastes are removed from the living space to a designated place such as a landfill. However, this advantage can be negated if the waste is not managed properly at the landfill sites or the right landfill type is not constructed. Under the guideline [5], four types of landfills are recognised as acceptable under specific conditions. The first is the sanitary landfill which includes leachate treatment and gas management. It is acceptable in an urban environment and has a low environmental impact from the disposal. Second is high density aerobic (HDA) landfill which includes spreading waste widely over the landfill site, extra compaction and leachate recirculation. It is also acceptable in an urban environment and has a low environmental impact with the exception of aesthetic. The third is the mechanically improved dumping which includes site fencing and separation of special or hazardous wastes. It confines wastes to the dumping site. The fourth is the manual improved dumping type. For this, wastes may be scattered around the dumping site [5] and it is not ideal for the study area either due to a large amount of waste generated or due to the likelihood of shifting the effects of waste to areas near the landfill site. Other reasons include protection of water resource, environmental and health implications and the likelihood of this type facing the most opposition such as nimby, nimn and banana syndrome from the local resident because it is perceived as pollution-laden. It is also more likely to be regarded as unacceptable to be located near places with socio-religious importance to the indigenes. It is also very important to manage landfill gas and prevent leachate infiltration to groundwater which can compromise the overall health and environmental performance near the landfill site [33]. Based on these, the sanitary landfill category is ideal for the study area for environmental management and for protecting the water resource which is already scarce in the district [8]. This will also enable the district to strive towards meeting Sustainable Development Goal 3 and 6 (SDG 3 and 6) on good health and well-being, and clean water and sanitation, respectively. The HDA landfill type could also be a good alternative to the sanitary landfill type. While advanced technologies in landfill sites such as landfill gas flaring and waste-to-energy type have been recommended by Margallo et al. [34], caution must be made not to neglect the fact that appropriate technology (ApproTech) for the locality is ideal. On the other hand, we agree with Margallo et al. [34] that 
whatever landfill type is adopted, the emphasis must also be made on the other forms of waste management such as reducing, reuse, and recycling. A combination of these would enhance waste management in the district and mitigate environmental impacts.

\section{Conclusion}

The study produced different landfill suitability maps based on criteria selection and prioritisation from the governmental guideline, the local technocrats, the indigenes and two optimal perspectives. The results show a low degree of overlap between the suitable areas for landfill siting from the governmental guideline and the rest of the perspectives. The other perspectives, however, have an average to high spatial overlap between the suitable areas for landfill siting. The study, therefore, revealed a classical case where project proponents could meet the governmental guideline and legally acquire permit, but the landfill project could be socially and even environmentally disruptive and catastrophically destructive to the local inhabitants. This is because the guideline for acquiring the permit is based on the requirement made from the national level without local inputs and concerns. The study also revealed that the local optimal is more likely to avoid local opposition to landfill siting than the technocrats and the global optimal. It seems as though the western educational system adopted in the country has eradicated the traditional belief systems to the background and as such the mentality of educated technocrats to a large extent is at variance to the pride and aspirations of the local people. It is therefore in order to conclude that this is the potential source of the impasse and agitations against landfill siting. Based on this, it is recommended that landfill guideline be designed at the local level and assisted by the top level. This should be premised on the fact that none of the three sets of stakeholders has all the requisite knowledge to solely design a landfill guideline for the district. Thus, the participation of all stakeholders in a mutual dialogue will result in a better criteria selection and prioritisation and the design of a guideline that will resolve the potential conflicts.

\section{Compliance and ethical standards}

Conflict of interest The authors declare that they have no conflict of interest.

\section{References}

1. Hoornweg D, Bhada-Tata P (2012) A global review of solid waste management. Urban Development and Local Government Unit, World Bank, Washington
2. Bilintoh TM, Stemn E (2015) Municipal solid waste landfill site selection in the Sekondi-Takoradi metropolis of Ghana using fuzzy logic in a GIS environment. J Environ Waste Manag 2:71-78

3. Komilis DP, Ham RK, Stegmann R (1999) The effect of municipal solid waste pretreatment on landfill behavior: a literature review. Waste Manag Res 17:10-19. https://doi.org/10.103 4/j.1399-3070.1999.00005.x

4. Yelsilnacar MI, Cetin H (2005) Site selection for hazardous wastes: a case study from the Gap Area, Turkey. Eng Geol Int J 81:371-388

5. MLGRD, EPA (2002) Landfill guidelines. Ministry of Local Government \& Rural Development (MLGRD) \& Environmental Protection Agency (EPA), Accra

6. Baabereyir A (2009) Urban Environmental problems in Ghana: a case study of social and environmental injustice in solid waste management in Accra and Sekondi-Takoradi. University of Nottingham, Nottingham

7. Kursah MB (2018) Resolving the landfill siting impasse: modelling technocratic and indigenous perspectives using GIS multicriteria approach. GeoJournal 83:707-724. https://doi. org/10.1007/s10708-017-9796-5

8. Ghana Statistical Service (2014) 2010 population and housing census - district analytical report: Bongo District. Ghana Statistical Service, Accra

9. Zulu S, Jerie S (2017) Site suitability analysis for solid waste landfill site location using geographic information systems and remote sensing: a case study of Banket Town Board, Zimbabwe. Rev Soc Sci 2:19-31. https://doi.org/10.18533/rss. v2i4.99

10. Sener S, Sener E, Karagüzel R (2011) Solid waste disposal site selection with GIS and AHP methodology: a case study in Senirkent-Uluborlu (Isparta) Basin, Turkey. Environ Monit Assess 173:533-554. https://doi.org/10.1007/s10661-010-1403-x

11. Kabak M, Erbaş M, Çetinkaya C, Özceylan E (2018) A GISbased MCDM approach for the evaluation of bike-share stations. J Clean Prod 201:49-60. https://doi.org/10.1016/j.jclep ro.2018.08.033

12. Chabuk AJ, Al-Ansari N, Hussain HM et al (2017) GIS-based assessment of combined AHP and SAW methods for selecting suitable sites for landfill in Al-Musayiab Qadhaa, Babylon, Iraq. Environ Earth Sci 76:209. https://doi.org/10.1007/s1266 5-017-6524-x

13. Vosoogh A, Baghvand A, Karbassi A, Nasrabadi T (2017) Landfill site selection using pollution potential zoning of aquifers by modified DRASTIC method: case study in Northeast Iran. Iran J Sci Technol Trans Civ Eng 41:229-239. https://doi.org/10.1007/ s40996-017-0054-3

14. Dar SN, Wani MA, Shah SA, Skinder S (2018) Identification of suitable landfill site based on GIS in Leh, Ladakh Region. GeoJournal. https://doi.org/10.1007/s10708-018-9933-9

15. Carrara A, Cardinali M, Guzzetti F (1992) Uncertainty in assessing landslide hazard risk. ITC J 2:172-183

16. Aniah P, Aosoglenang AT, Bonye SZ (2014) Behind the myth: indigenous knowledge and belief systems in natural resource conservation in North East Ghana. Int J Environ Prot Policy 3:104-112. https://doi.org/10.11648/j.ijepp.20140203.11

17. Suman $P(2012)$ Location allocation for urban waste disposal site using multi criteria analysis: a case study on Nabadwip municipality, West Bengal, India. Int J Geomat Geosci 3:1

18. Şener B, Süzen ML, Doyuran V (2006) Landfill site selection by using geographic information system. Environ Geol 49:376-388. https://doi.org/10.1007/s00254-005-0075-2

19. Kursah MB (2014) Geo-environmental assessment to identify a least-cost road in Ghana. Appl GIS 10:1-22

20. Jiang H, Eastman RJ (2000) Application of fuzzy measures in multi-criteria evaluation in GIS. Int J Geogr Inf Syst 14:173-184 
21. Rafiee R, Ematolah K, Abdolrassoul SM et al (2011) Siting transfer station for municipal solid waste using a spatial multi-criteria analysis. Environ Eng Geosci 17:143-154

22. Shukla G, Shashi M, Jain K (2012) Decision support system for selecting suitable site for disposing solid waste of township. Int J Remote Sens GIS 1:2-11

23. Arthur M (2019) Close down Kpone landfill site-residents. Ghana Broadcasting Corporation (GBC), Accra

24. Bampoe D (2019) Adasawase resident rejects water project. Dly. Guide Netw

25. Omrani G, Rezaiee MM, Monvari M, Nasiri P (1998) Assessment of environmental impact of municipal solid waste transfer stations in Tehran City. J Environ Stud 1:28-39

26. Macharia PM, Mundia CN (2014) GIS analysis and spatial modelling for optimal oil pipeline route location. A case study of proposed Isiolo Nakuru pipeline route. In: International conference on sustainable research and innovation, pp 91-94

27. Goulet D (1986) Three rationalities in development decision making. World Dev 14:301-317

28. Kursah MB (2017) Least-cost pipeline using geographic information system: the limit to technicalities. Int J Appl Geospat Res 8:1-15. https://doi.org/10.4018/ijagr.2017070101

29. Aniah $P$, Yelfaanibe $A$ (2016) Learning from the past: the role of sacred groves and shrines in environmental management in the Bongo District of Ghana. Environ Earth Sci 75:916. https://doi. org/10.1007/s12665-016-5706-2

30. Pellicani R, Spilotro G (2015) Evaluating the quality of landslide inventory maps: comparison between archive and surveyed inventories for the Daunia region (Apulia, Southern Italy). Bull Eng Geol Environ 74:357-367. https://doi.org/10.1007/s1006 4-014-0639-z

31. Erbaş $M$, Kabak M, Özceylan E, Çetinkaya C (2018) Optimal siting of electric vehicle charging stations: a GIS-based fuzzy multicriteria decision analysis. Energy 163:1017-1031. https://doi. org/10.1016/j.energy.2018.08.140

32. Çetinkaya C, Kabak M, Erbaş M, Özceylan E (2018) Evaluation of ecotourism sites: a GIS-based multi-criteria decision analysis. Kybernetes 47:1664-1686. https://doi.org/10.110 8/K-10-2017-0392

33. Manfredi S, Christensen TH (2009) Environmental assessment of solid waste landfilling technologies by means of LCA-modeling. Waste Manag 29:32-43. https://doi.org/10.1016/j.wasma n.2008.02.021

34. Margallo M, Ziegler-Rodriguez K, Vázquez-Rowe I et al (2019) Enhancing waste management strategies in Latin America under a holistic environmental assessment perspective: a review for policy support. Sci Total Environ 689:1255-1275. https://doi. org/10.1016/j.scitotenv.2019.06.393

Publisher's Note Springer Nature remains neutral with regard to jurisdictional claims in published maps and institutional affiliations. 